\title{
Mobile Learning Technologies for Education: Benefits and Pending Issues
}

\author{
Santiago Criollo-C ${ }^{1, *(\mathbb{D}}$, Andrea Guerrero-Arias ${ }^{2}$, Ángel Jaramillo-Alcázar ${ }^{1}{ }^{\mathbb{D}}$ and Sergio Luján-Mora ${ }^{3}(\mathbb{D})$ \\ 1 Escuela de Ingeniería en Tecnologías de la Información, FICA, Universidad de Las Américas, \\ Quito 170125, Ecuador; angel.jaramillo@udla.edu.ec \\ 2 Departamento EGB/BGU, Jezreel International Christian Academy, Quito 170520, Ecuador; \\ andrea.guerrero@jezreelacademy.edu.ec \\ 3 Departamento de Lenguaje y Sistemas Informáticos, Universidad de Alicante, 03690 Alicante, Spain; \\ sergio.lujan@ua.es \\ * Correspondence: luis.criollo@udla.edu.ec; Tel.: +59-398-471-1052
}

Citation: Criollo-C, S.;

Guerrero-Arias, A.; Jaramillo-Alcázar, Á.; Luján-Mora, S. Mobile Learning Technologies for Education: Benefits and Pending Issues. Appl. Sci. 2021, 11, 4111. https://doi.org/10.3390/ app11094111

Academic Editor:

Carlos Alario-Hoyos

Received: 26 March 2021

Accepted: 16 April 2021

Published: 30 April 2021

Publisher's Note: MDPI stays neutral with regard to jurisdictional claims in published maps and institutional affiliations.

Copyright: (c) 2021 by the authors. Licensee MDPI, Basel, Switzerland. This article is an open access article distributed under the terms and conditions of the Creative Commons Attribution (CC BY) license (https:// creativecommons.org/licenses/by/ $4.0 /)$.
Abstract: Today's world demands more efficient learning models that allow students to play a more active role in their education. Technology is having an impact on how instruction is delivered and how information is found and share. Until very recently, the educational models encouraged memorization as an essential learning skill. These days, technologies have changed the educational model and access to information. Knowledge is available online, mostly free, and easily accessible. Reading, sharing, listening and, doing are currently necessary skills for education. Mobile devices have become a complete set of applications, support, and help for educational organizations. By conducting an analysis of the behavior and use of mobile devices on current students, efficient educational applications can be developed. Although there are several initiatives for the use of mobile learning in education, there are also issues linked to this technology that must be addressed. In this work, we present the results of a literature review of mobile learning; the findings described are the result of the analysis of several articles obtained in three scientific repositories. This work also lists certain issues that, if properly addressed, can avoid possible complications to the implementation of this technology in education.

Keywords: mobile learning; learning; education; mobile education; technologies

\section{Introduction}

The digital revolution is transforming education by using information and communication technologies (ICTs) to improve students' learning outcomes. In the last 50 years, changes can be seen in every area of society, such as culture, entertainment, and social interaction. However, the current educational model is very similar to how it was back then [1].

Although there is evidence of the negative impact Internet access, social networks, and the use of mobile devices could cause in current education [2], the use of mobile technologies is gaining ground in education [3]. Due to the characteristics of mobile devices, and the inexperience of teachers and educational institutions, students may experience distractions in their learning and may be involved in inefficient educational methodologies [4]. Digital revolution is transforming these educational models, involving students, teachers, and educational institutions in this process [5]. The appropriate use of digital technologies and a pedagogical approach in the design of learning models could generate an improvement in the learning results of the students [6].

Nowadays, learning using portable digital devices, such as mobile learning (mlearning), expands into all daily activities that are related to acquiring knowledge. The study of educational innovations has become increasingly important in educational research [7]. Mobile devices, clearly, are growing faster than the world's population. Cisco, 
in its Annual Internet Report (2018-2023) published in March 2020, forecasts that smartphones will have the second-fastest growth by the end of 2023. As seen in Figure 1, mobile subscriptions will increase at a 2 percent annual growth rate. This means that more than $70 \%$ of the world's population will have a mobile phone in 2023 [8].

Certainly, the penetration of mobile devices has a direct impact on the way young people access information [9]. Mobile devices allow students to improve the way they acquire knowledge. Education is there to ensure all students can benefit from a learning experience [10]. To do so, when considering our ever-changing world, teachers and educational institutions should embrace technology, as an innovative new methodology, to enable their students to achieve their goals [3]. This does not mean the introduction of technology in the classroom is a guarantee of success [4]. In theory, these new technological methodologies can be easily adopted by the new generations of "digital natives." This is due to the easy handling and adaptation to new technologies since this generation grew up with access to the Internet, mobile devices, and social networks [11].

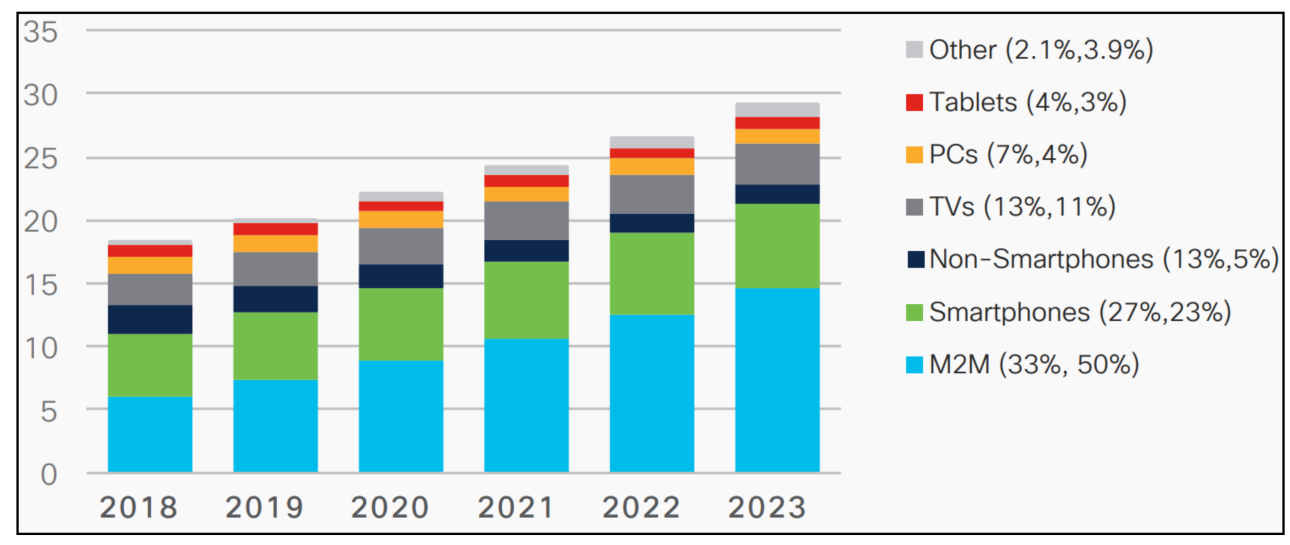

Figure 1. Global device and connection growth (Source: Cisco Annual Report, 2018-2023 [8]).

The use of m-learning in the teaching and learning process would be a more natural and effective way of learning for this generation [10]. In many places, mobile technology may, possibly, be the only platform available to access educational information [12]. It is for this reason that m-learning systems are allowing people and vulnerable groups to access knowledge [13]. Technological advances have accelerated the development of multiple applications, among which those that can be used as support in education stand out [14].

Hence, the rules, policies, and strategies of educational institutions must change perspective, providing opportunities for new approaches to active learning [15]. Technology "together with educational models" enables teachers to control their students remotely and manage learning activities in a more effective way. For this reason, mobile technology in education generates an impact on learning, since students are no longer limited by the traditional classroom [16]. In addition, mobile devices allow students to easily access educational content from anywhere and at anytime [9].

There has always been a close relationship between educational methodologies and learning outcomes [17], as both impact each other. In the last decade, pedagogical initiatives using m-learning have helped educational institutions achieve certain learning outcomes [18]. Furthermore, most students are motivated to learn using their own mobile devices [19].

M-learning is an innovation that definitely will suffer changes based on new trends in education and technology. Much of the educational content can be easily understood by using innovative educational methodologies [20]. An immersive experience that visually demonstrates how variables interact in a scientific model will definitely improve understanding of the topics taught [21]. These aspects of learning are aligned with the features and capabilities of mobile devices. Mobile applications are an easily accessible tool that has the potential to contribute to education [22]. 
Mobile technology will enable educational institutions to utilize a set of features such as flexibility, ubiquity, and portability in learning that will be of great benefit to teachers and students in the new digital era [23]. To take advantage of students' interest and the benefits of m-learning in education, educational institutions and their teachers should design innovative learning methodologies $[24,25]$. Due to the accessibility and opportunities offered by this technology, it is important to investigate how to harness and exploit the benefits of m-learning as well as to identify its main problems. That is why this paper, through a previous literature review aims to explore and identify the benefits of using mobile devices in current education. In the same way, it identifies the main problems to be overcome for the proper deployment of this technology in educational environments.

In this article, the results of a literature review on m-learning are presented. The items involved were found by a search string in three scientific databases. The findings show the great progress that m-learning has made in the educational field. In addition, it describes the benefits and lists the issues that must be addressed to avoid complications with the deployment of mobile technologies in education. The results presented are useful both for educators and for institutions that seek to integrate new methodologies in their teaching-learning process. This work is made up of seven sections. The first section defines m-learning technology and the motivation of this research. The second section Identifies of need for a literature review study. The third section describes how mobile devices are currently used. The fourth section outlines the methodology used to describe the benefits and issues of using m-learning. The fifth section shows the discussion and the results, the sixth section describes the limitations of the work. Finally, the seventh section details the conclusions and the direction for future research.

\section{Identification of Need for a Literature Review Study}

To demonstrate the need for a literature review on the benefits and problems the use of mobile devices can generate, a search for reviews and similar publications related to the benefits and problems in the use of m-learning in education was carried out at the suggestion of some research papers [1,26,27]. For the search, we used a search string with keywords such as, "mobile learning," "education," and "review" in the Scopus, IEEE Xplore, and Web of Science (WoS) repositories. The search string used was:

“((mobile learning) OR (mlearning) OR (m-learning) AND (review) OR (literaturereview) OR (systematic literature-review))".

The search yielded 58 articles, of which there were 26 repeated, leaving us with 32 literature reviews on the use of m-learning in various educational contexts. The years that contributed the most initiatives were 2020 with 7 papers, 2018 with 6 articles, and 2017 with 5 research papers. Of the 32 initiatives found, only 4 are related to our work.

Sobral [3] conducted a bibliometric review of the widespread use of mobile devices as an opportunity and a necessity for higher education institutions. He did so from 2003-2019, using two scientific repositories (WoS and Scopus).

Wainana, Maina, and Nzuki [28], conducted a review of the considerations for successful open distance learning and its access to higher education. Their results show higher education institutions should consider improving technological infrastructure and the incompatibility of mobile devices with learning management systems as well as suggestions for improving instructors' andragogical skills in m-learning, addressing student concerns, and providing motivational incentives for proper use of m-learning.

Crompton and Burke [29] showed a synthesis of research on m-learning in the years 2010-2016 for higher education settings. The motivation of this research is to find results on methodologies, educational level, educational context, types of devices, and geographical distribution of studies. Its main findings indicate most studies focused on the impact of m-learning on student achievement. Language learning was the educational dimension with the most initiatives created. The findings reveal that $74 \%$ of the work involved undergraduate students, also indicating that $54 \%$ of initiatives were designed for a formal 
educational context. Furthermore, it encourages higher education instructors to consider innovating their academic style with m-learning.

Alrasheedi, Capretz, and Raza [30] conducted a systematic review of the literature on the factors involved in the success of m-learning in higher education. The results show factors necessary for successful acceptance of m-learning. One example is the user's perception of this technology and whether he/she considers the use of this pedagogical model to increase his/her efficiency and productivity. These results can help to identify the underlying aspects to reduce the adoption of $\mathrm{m}$-Learning by university students.

Summarizing, the first study indicates publication rates on the use of m-learning have been increasing from 2003 to 2019. It also presents the journals that have published the most initiatives on the mobile theme, the main approaches to m-learning in higher education, and the countries which have contributed the most research on this topic. The second study shows some considerations educational institutions should take into account for the proper deployment of m-learning. For example, improving the technological infrastructure and addressing the incompatibility of mobile devices with the learning management systems used in the institutions. The third study synthesizes the methodologies, educational level, educational context, types of devices, and geographical distribution of studies using mlearning in higher education. Finally, the last study shows a systematic review of the different success factors, seen from the student's side, that need to be addressed in the correct acceptance of mobile technology. However, these initiatives do not synthesize all the possible benefits and problems provided from the student, teacher, and educational institution sides. In addition, this review is current as of 2020. Therefore, these articles do not cover the objective of our research on the benefits and pending problems in the use of mobile devices in education.

\section{Use of Mobile Devices in Education}

According to Kukulska et al. [31], students use mobile devices mainly for learning, social interaction, entertainment, and work. In general, the most prominent uses in the area of learning are: immediate access to information and answers, reading e-books, listening to podcasts, using applications for learning purposes, educational videos, educational games, serious games, accessing documents or document libraries, participating in online lessons and tutorials, receiving live-streamed lectures, accessing video clips or audio libraries, reading asynchronous publications, participating in virtual learning communities, etc $[32,33]$. Less frequent uses of these devices include creating an educational resource, listening to television programs and educational documentaries, recording the voice of a presentation, taking pictures in reference books, socializing with experts in different areas of knowledge, feeding a blog, and interacting in an educational way in social networks [31]. Language learning is also a popular activity among students [34]. As cell phones combine the functions of audio and video playback, use of GPS, sensors and gyroscopes, the world of learning has become more mobile, more ubiquitous, more flexible, and much more exciting [34,35].In recent years, the educational model has benefited from the incorporation of technologies that enrich the teaching-learning process. An advanced m-learning technique is an augmented reality (AR). This technique shows digital information on images captured by a mobile device [36]. AR allows the display of stored data and 3D images, making any educational environment interactive and innovative. In the same way, virtual reality (VR) contributes with an entirely immersive learning style [37]. This characteristic, surely, allows improving the understanding of specific educational topics. For example, the Human Muscular Arm Avatar (HMAA) project, developed by Yusuf Ozgur Cakmak, is a novel AR/VR tool. HMAA enables the University of Otago medical students to transform and enhance the learning experience in Anatomy through their mobile devices [38].

The use of mobile devices in education presents many opportunities as well as many challenges [34]. From a pedagogical perspective, the main challenge focuses on clearly identifying what is best learned in the classroom, what should be learned outside the classroom, and the ways in which these two can coexist [39]. 
Either way, whether for communication needs or as educational and leisure tools, mobile devices are present in the daily lives of many people, especially young people. Today, the generation born between 2000 and 2012 is called Generation Z [40,41]. These young people are digital natives, respond to instant gratification, enjoy social networks, Internet access, demand much of themselves, and are under pressure to succeed [11,42]. They grew up with access to the Internet and mobile devices, so they are a potential group where m-learning can be an attractive methodology in the teaching-learning challenge [41].

\section{Methods and Materials}

M-learning has evolved rapidly, so nowadays, the use of mobile devices is not considered a technological trend focused only on people interested in devices and technologies. This is evident in the variety of initiatives adopting m-learning as a new methodology able to generate opportunities to contribute to education and learning [42]. To achieve this objective, a previous literature review was conducted with several scientific contributions on m-learning and the opportunities it generates for the improvement of education, as well as several issues that must be overcome to successfully implement this technology. The search for information was carried out in three databases containing a catalog of high-impact scientific references. For reasons of theoretical expiration, no article is older than 10 years (2010-2020).

For this study, the search was limited to IEEE Xplore, Scopus, and WoS because they are considered the largest and most widespread databases used to search the scientific literature. In addition, there were several articles repeated in the three chosen repositories; to avoid further overlap, no other databases were added in this research.

For the search of these articles, we used a search string modified to suit each scientific repository. This included keywords such as, "mobile learning," "education," "students," and "m-learning." The search was carried out in Scopus, IEEE Xplore, and WoS. The search string used is presented below:

“((Mobile learning) OR (mlearning) OR (m-learning)) AND ((education) OR (higher education) OR (students)) AND ((benefit) OR (strengths) OR (challenge) OR (issue))".

Articles were chosen for review based on a three-step methodology as can be seen Table 1:

(1) FIRST STEP. The scientific repositories were searched and 76 articles were obtained.

(2) SECOND STEP. Once the results were obtained, the exclusion criteria were applied, these were the following:

- Discard duplicate articles.

- Discard articles that are not written in English.

- Discard publications that do not correspond to conferences and journals on topics related to computer science and education.

(3) THIRD STEP. All irrelevant articles were discarded when reading the article abstract.

Table 1. Number of articles used in this study.

\begin{tabular}{ccccc}
\hline Articles & IEEE Xplore & Wos & Scopus & All \\
\hline Total Articles (First step) & 33 & 21 & 22 & 76 \\
Selected Articles (Second step) & 27 & 15 & 17 & 59 \\
Relevant Articles (Third step) & 18 & 10 & 8 & 36 \\
\hline
\end{tabular}

\section{Results Analysis and Discussion}

Table 1 shows the total number of articles found according to the search criteria in the three databases chosen. The analysis of the content of each of the chosen articles yielded 10 generalizations about the different benefits of the use of mobile devices. In addition, 6 themes were found helping to have a much broader view of all the issues that must be faced for an adequate implementation of m-learning in today's education. 
The general themes associated with the benefits of m-learning are constructivist learning, student behavior, learning spaces, collaborative learning, informal and selfdirected learning, teacher resources, technology and support, affordability and portability, availability and flexibility, and motivational learning. On the other hand, the issues inherent to the use of this technology are aligned with the content in mobile applications and the design of activities for m-learning, educators, technology, students, learning, and educational institutions. These generalizations are the results of the grouping of multiple benefits and characteristics mobile devices provide to students, educational institutions, and teachers. In the same way, the generalizations of the problems are based on multiple challenges, problems, issues, and weaknesses faced by the deployment and use of this technology. This summary of this analysis can be seen in Tables 2 and 3.

Table 2. Generalization of the issues of using mobile learning in education.

\begin{tabular}{ll}
\hline \multicolumn{1}{c}{ Generalization } & \multicolumn{1}{c}{ Issues of Mobile Learning } \\
\hline Applications & Mobile content design, real learning experiences, pedagogical design \\
\hline Educators & $\begin{array}{l}\text { Difficult understanding, difficulty of use, discomfort of use, culture of rejection of change, extra } \\
\text { workload, updating of knowledge, extra effort }\end{array}$ \\
\hline Technological & $\begin{array}{l}\text { Security and privacy, connectivity restrictions, equipment cost, technical deficiencies of the device, } \\
\text { Internet access or mobile data, Internet access speed }\end{array}$ \\
\hline Students & Application usability, device accessibility, distraction/ restrictive conditions, enjoyment, cost \\
\hline Educational Institutions & $\begin{array}{l}\text { Technological infrastructure, strategies for implementation and deployment, prohibitions, digital } \\
\text { security for students, cost }\end{array}$ \\
\hline Learning & $\begin{array}{l}\text { Technological infrastructure, strategies for implementation and deployment, prohibitions, digital } \\
\text { security for students, cost }\end{array}$ \\
\hline
\end{tabular}

Table 3. Generalization of the benefits of using mobile learning in education.

\begin{tabular}{|c|c|}
\hline Generalization & Benefits of Mobile Learning \\
\hline Constructivist Learning & $\begin{array}{l}\text { Learning methods, participation, contextual learning, new learning opportunities, challenge in } \\
\text { education }\end{array}$ \\
\hline Student behavior & $\begin{array}{l}\text { Improved retention, improved performance, involves the student, motivation and autonomy, } \\
\text { experiential learning, self-directed, active participation, facilitates coordination, cooperation, } \\
\text { collaboration }\end{array}$ \\
\hline Learning & $\begin{array}{l}\text { learning aligned with educational objectives, strategic learning, best/innovative learning methods, } \\
\text { portability, ubiquity, connectivity, learning in multiple, conceptual and social physical spaces, lifelong } \\
\text { learning }\end{array}$ \\
\hline Collaborative Learning & $\begin{array}{l}\text { Improved interaction inside and outside the classroom, collaboration and communicationinteractive } \\
\text { and accessible learning, project-based learning, improved teacher-student communication, improves } \\
\text { student-student communication }\end{array}$ \\
\hline $\begin{array}{l}\text { Informal and self-directed } \\
\text { learning }\end{array}$ & $\begin{array}{l}\text { Formal and informal learning, participation, convenience, and achievement, attractive learning, } \\
\text { self-directed learning, informal learning }\end{array}$ \\
\hline Resources for teachers & $\begin{array}{l}\text { Adapted to learning needs, innovative pedagogies to support teachers, natural and intuitive } \\
\text { interface, immediate delivery of feedback, easier team work, help teachers with new literacy, new } \\
\text { social interactions }\end{array}$ \\
\hline Technology and support & $\begin{array}{l}\text { Service-oriented architectures, learning moments, commercial tools for creating and deploying } \\
\text { content, improve the learning process, free access to educational platforms, high implementation } \\
\text { speed }\end{array}$ \\
\hline $\begin{array}{l}\text { Affordability and } \\
\text { portability }\end{array}$ & Accessible and located learning, portable educational technology, affordable educational technology \\
\hline Availability and flexibility & $\begin{array}{l}\text { Ubiquitous access to information, local and mobile learning, availability and accessibility, content } \\
\text { available, encourage learning and participation in multiple physical spaces }\end{array}$ \\
\hline Motivational Learning & Easy and interesting learning, learning that generates achievement and enjoyment \\
\hline
\end{tabular}


The summary of these generalizations found in the analysis of each article and the findings discovered are shown in two concept matrices in Tables 4 and 5.

The general analysis of the research indicates students are predisposed to use their mobile devices in the teaching-learning process because they are familiar with their utilization [32]. Moreover, the success of m-learning is highly dependent on the educational institution, the teachers involved, and the students [43]. Due to the physical characteristics of mobile devices, technological limitations are one of the main issues this technology has for its use in the educational area [34].

The generalizations proposed to identify the benefits of using m-learning found in the research are detailed below.

\subsection{Benefits of Learning Using Mobile Devices}

The benefits found in this research will be helpful for the correct deployment of m-learning technology and its use by teachers and students.

\subsubsection{Constructivist Learning (A)}

Activities that encourage learners to actively construct new ideas or concepts based on their prior and current knowledge [42,44,45]. For example: m-learning allows learners to adapt existing mobile features to meet their needs, develop their interests, and construct their own learning [46,47]. Mobile technology offers new learning opportunities extending beyond traditional activities, allowing participation, challenge, and competition of participants [48,49].

\subsubsection{Student Behavior (B)}

Activities that lead to a change in the observable actions of learners based on learning [49]. M-learning allows for actively controlling the acquisition process, this leads to an increase in learner motivation [50-52]. In addition, mobile technologies foster selfdirected learning, which encourages students to participate more actively in their learning process $[34,52]$.

Table 4. Mobile learning benefits matrix.

\begin{tabular}{|c|c|c|c|c|c|c|c|c|c|c|}
\hline \multirow{2}{*}{ Relevant Articles } & \multicolumn{10}{|c|}{ Benefits of Mobile Learning } \\
\hline & A & B & $\mathrm{C}$ & $\mathbf{D}$ & $\mathrm{E}$ & $\mathbf{F}$ & G & $\mathbf{H}$ & $\mathbf{I}$ & $\mathbf{J}$ \\
\hline [53] & & & & & & & $x$ & & & \\
\hline$[44]$ & $x$ & & $x$ & & $x$ & & $\lambda$ & & & \\
\hline [49] & & $x$ & & $x$ & & & & & & \\
\hline$[50]$ & & $\begin{array}{l}x \\
x\end{array}$ & & & & $x$ & & & & \\
\hline$[54]$ & & $x$ & $x$ & $x$ & & $x$ & & $x$ & $x$ & \\
\hline$[47]$ & $x$ & $x$ & & $x$ & $x$ & & & & $x$ & \\
\hline [55] & & $x$ & & & & & & & & $x$ \\
\hline$[52]$ & & $x$ & & $x$ & & & & & $x$ & \\
\hline$[56]$ & & $x$ & & & & $x$ & $x$ & & & \\
\hline$[58]$ & & $\chi$ & & & & & $\lambda$ & & $x$ & \\
\hline [59] & & & & & & & & & $x$ & $x$ \\
\hline$[60]$ & & & & & & $x$ & & & & \\
\hline$[61]$ & $x$ & $\begin{array}{l}x \\
x\end{array}$ & & $\begin{array}{l}x \\
x\end{array}$ & $x$ & & & $x$ & $\chi$ & $\chi$ \\
\hline$[45]$ & $\hat{x}$ & $\hat{x}$ & & & & $x$ & & & & \\
\hline [63] & & & & $x$ & & & & & $x$ & $\begin{array}{l}x \\
x\end{array}$ \\
\hline$[65]$ & & & & & $x$ & & & & & $\begin{array}{l}\lambda \\
x\end{array}$ \\
\hline [66] & & & & & & & $x$ & & & \\
\hline$[67]$ & & & $x$ & $x$ & $x$ & $x$ & & & $x$ & $x$ \\
\hline$[48]$ & $x$ & & & & & & & & $x$ & $x$ \\
\hline [68] & & $x$ & & & $x$ & & & $x$ & $\lambda$ & $\lambda$ \\
\hline [69] & & & & $x$ & & $x$ & $x$ & & & \\
\hline
\end{tabular}




\subsubsection{Learning Spaces (C)}

Learning is motivated through activities taking place in an authentic context and culture $[34,70]$. Currently, mobile technologies are proving to be well aligned with strategic objectives in education [55,71]. M-learning has the potential to promote learning and engagement of students and teachers in multiple physical, conceptual, and social spaces $[34,57]$.

\subsubsection{Collaborative Learning (D)}

Social interaction can promote learning [53,72]. Mobile devices enable educational socialization at a distance and promote collaboration and communication among students, teachers, and teacher-students $[50,59]$. They enhance learning through collaboration, and m-learning could also help create more personalized learning experiences $[32,73]$.

\subsubsection{Informal and Self-Directed Learning (E)}

Activities outside of a dedicated learning environment supporting learning [32,47]. Mobile devices enable informal learning, which is self-directed, voluntary, and guided by individual needs and interests [74]. This learning provides opportunities for anyone with a mobile device and an Internet connection, regardless of age, background, or academic level [75].

\subsubsection{Resources for Teachers (F)}

Activities that help teachers coordinate resources for learning experiences [56,76]. There are initiatives to help teachers relate content and pedagogy to the functionalities and purposes of specific mobile applications, and there are mobile tools with the potential to support teachers in understanding and developing new literacies [67,74].

\subsubsection{Technology and Support (G)}

Initiatives that support the deployment of technology and content. Students and teachers have the opportunity to quickly and inexpensively access different platforms, forms, and application resources through mobile phones [57,77]. Some free commercial tools allow instructors to quickly create and implement their course content $[66,78]$. Cloud computing reduces costs, creates a greater focus on learning, and increases the speed of m-learning implementation $[69,79]$.

\subsubsection{Affordability and portability $(\mathrm{H})$}

Intrinsic characteristics of mobile technology provide access to learning that might not otherwise exist [32,54]. Learning through mobile devices ensures access to education to people who, otherwise, would not have the opportunity to actively participate in this process $[34,80]$.

\subsubsection{Availability and Flexibility (I)}

Intrinsic characteristics of mobile technology allows ubiquitous access to learning and to all educational resources $[58,64]$. The use of mobile devices allows people to move and access content and information from anywhere [35,81]. They are also considered a tool for accessing content by storing it locally on the device or in cloud services $[47,69]$.

\subsubsection{Motivational Learning (J)}

Intrinsic characteristics of mobile technology provide a wide variety of learning paths, making education easy, interesting, and fun [10,31]. Both mobile and gaming technologies are considered fertile ground for developing resources to motivate learning [55]. Currently, mobile devices are beneficial in terms of engagement, convenience, achievement, and enjoyment, resulting in increased participation and motivation towards learning [59,63].

In recent years, several m-learning research projects have been conducted in formal and informal educational settings $[47,67]$. The results have been encouraging, showing that 
mobile devices definitely generate motivation to learn [32]. This technology is accessible to individuals, educational systems, and countries where other learning models have failed [61]. The use of mobile devices can intensify, refine, and enrich learning due to the intrinsic characteristics of mobile devices associated with education [67].

Figure 2 shows the benefits of the use of m-learning in education and which of these is the most evident in the reading of the articles found for this research.

As can be seen in Figure 2, the benefit that is most associated with the items analyzed is student behavior (with 11 articles). In other words, academic activities carried out using mobile devices produce a positive change in the observable actions of students. This is due to the fact that the use of mobile technology allows active control of the learning process, and this produces an increase in student motivation, as well as encouraging self-directed learning.

In addition, collaborative learning and the availability and flexibility offered by mobile technologies, each with nine articles, appear in second place as benefits of the use of m-learning. Mobile devices allow educational socialization at a distance and promote collaboration between students, and the use of mobile devices allows users to move and access content and information from anywhere and at any time.

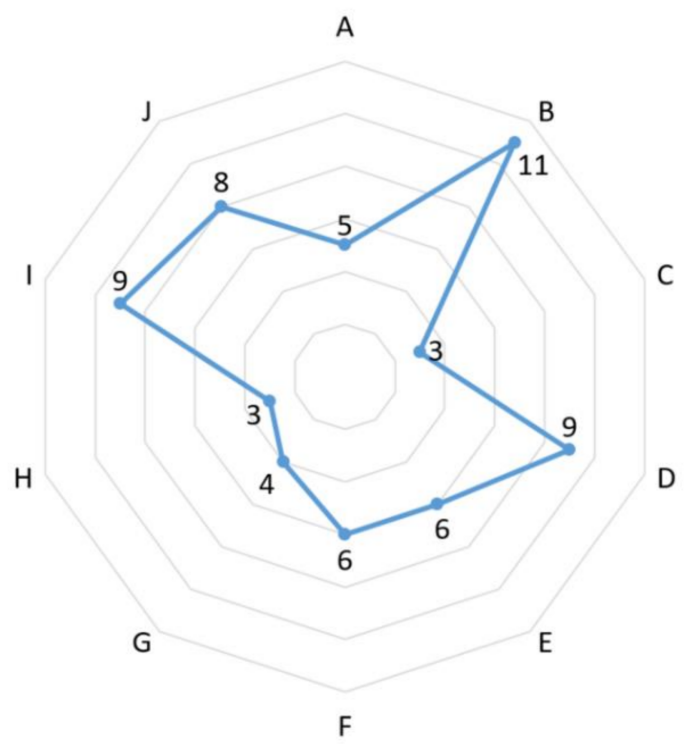

Figure 2. Benefits of mobile learning, A: Constructivist Learning; B: Student behavior; C: Learning spaces; D: Collaborative Learning; E: Informal and self-directed learning; F: Resources for teachers; G: Technology and support; H: Affordability and portability; I: Availability and flexibility; J: Motivational Learning.

\subsection{Issues Inherent to Mobile Technology}

As it has been shown in the previous section, the use of mobile technology offers many advantages and benefits, but there are also issues to be addressed to avoid complications when using them.

\subsubsection{Applications (A)}

Features related to the design of educational application content that produce real experiences in the learner [57]. The use of mobile devices requires the development of very specific user interfaces, due to the limitations of battery consumption, size, and input and output interfaces [32]. The m-learning should try to create a real learning environment and highly emotional mobile applications that are loved by consumers [34]. 


\subsubsection{Educators (B)}

The inherent challenge for educators has to do with several aspects. The first is the generation, the "digital immigrants" who are trying to teach a generation of "digital natives" $[10,11]$. These two groups speak different languages, and there is quite a large technological gap between them [44]. A large number of teachers do not have adequate knowledge of how to use mobile technology to enhance the learning process [47]. Teachers may need to spend more time preparing content for mobile devices or monitoring students' learning outside the classroom [65].

\subsubsection{Technological (C)}

The slow adoption of mobile technology may be due to concerns about information security and privacy [47]. Storage size, limited memory, and battery life are some of the barriers to this technology [56]. Low mobile storage capacities and small screens limit the amount, and type, of information that can be displayed. Wireless bandwidth is limited and may degrade with increasing numbers of users [48]. Furthermore, access to technology in some places remains very expensive, so students and parents cannot afford to purchase a tablet or smartphone with sufficient capabilities to support learning [68].

Table 5. Matrix of issues associated with mobile learning.

\begin{tabular}{|c|c|c|c|c|c|c|}
\hline \multirow{2}{*}{ Relevant Articles } & \multicolumn{6}{|c|}{ Issues of Mobile Learning } \\
\hline & A & B & $\mathrm{C}$ & D & $\mathbf{E}$ & $\mathbf{F}$ \\
\hline [53] & & $x$ & $x$ & $x$ & & \\
\hline$[44]$ & & $x$ & & $x$ & & \\
\hline [49] & & & $x$ & & & \\
\hline [50] & & & $x$ & $x$ & & \\
\hline [34] & & & $x$ & $x$ & & \\
\hline [54] & & $x$ & $x$ & $x$ & & \\
\hline [47] & & $x$ & $x$ & & $x$ & \\
\hline [55] & & & $x$ & & $x$ & \\
\hline [52] & & & $x$ & $x$ & & \\
\hline [56] & & & $x$ & & $x$ & $x$ \\
\hline [57] & $x$ & & & & & \\
\hline [58] & & & $x$ & & & \\
\hline [59] & & & $x$ & & $x$ & $x$ \\
\hline [60] & $x$ & & & $x$ & & \\
\hline [61] & & & $x$ & & & \\
\hline [62] & & & $x$ & & & $x$ \\
\hline [45] & $x$ & & & & $x$ & \\
\hline [63] & & $x$ & & $x$ & & \\
\hline [64] & & & $x$ & & & $x$ \\
\hline [65] & & & $x$ & & $x$ & $x$ \\
\hline [66] & & $x$ & $x$ & & & \\
\hline [67] & & & & & $x$ & \\
\hline [48] & & & $x$ & $x$ & & \\
\hline [31] & & & $x$ & & $x$ & \\
\hline [68] & & & & & & $x$ \\
\hline [69] & & & $x$ & $x$ & $x$ & \\
\hline
\end{tabular}

A: Applications; B: Educators; C: Technological; D: Students; E: Educational Institutions; F: Learning.

\subsubsection{Students (D)}

The main problem is the low acceptance of this new type of technology due to a possible distraction that diverts them from the objective in the teaching and learning process [54]. Others include ethical problems, lack of institutional support, technical and accessibility limitations, insufficient experience, prohibitions of cell phones in schools, and curricular adaptations [63]. 


\subsubsection{Educational Institutions (E)}

Their lack of support stems from concerns about potential issues such as cyberbullying, privacy, record keeping, storage, sharing of classroom experiences and artifacts, informed consent of parents and students, and e-safety [47]. There are institutions claiming the use of mobile devices is due to a global trend of entertainment and various forms of instant and superficial communication through social networks [48]. It is a legitimate consideration to use the school as a protection against distracting habits and to promote attitudes necessary for serious and successful learning [60].

\subsubsection{Learning $(\mathrm{F})$}

The teacher has to design activities using mobile devices while also having cognitive factors and promoting fluency and accuracy in learning [31]. Due to the various activities to be performed on the mobile device, it is difficult for teachers to monitor the actual learning of their students [62].

The issue inherent to the use of this technology are aligned with the content of the applications and the effective design of activities for m-learning [45]. Although the correct use of m-learning depends on teachers and students, educational institutions have an important role to play in its successful deployment [55]. An important aspect to consider is the physical characteristics of mobile devices because their small and limited input and output interfaces definitely represent an issue to face [61]. The mobility and ubiquity of m-learning technology depends on the educational context in which it is developed. M-learning can take learning outside the classroom, far from the reach and supervision of the teacher, which generates resistance to the use of m-learning by educational institutions and teachers. These characteristics of mobile devices can easily be perceived as a threat that can obviously affect the proposed learning outcomes [67].

Figure 3 shows the main problems of the use of m-learning in education and which of these is the most evident in the reading of the articles found for this research.

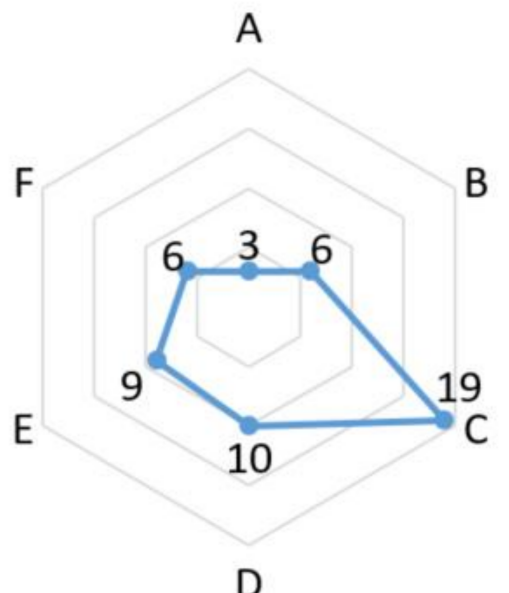

Figure 3. Issues of mobile learning, A: Applications; B: Educators; C: Technological; D: Students; E: Educational Institutions; F: Learning.

As can be see Figure 3 indicates, there are 19 articles stating that the most common problems associated with mobile technology have to do with technology deployment. Storage, poor battery life, small screens, wireless bandwidth, and Internet access are some of the problems inherent in mobile technology. There are also two major problems that were found in 10 and 9 articles each: students and educational institutions. This is due to the fact that mobile technology takes learning away from the control of the teacher and the educational institution, which can be perceived as a threat. 


\subsection{Articles Overview}

Table 6 shows all the selected studies and some data extracted such as first author, nationality of the first author, year of publication, and place of publication. As can be seen in Table 6, none of the researchers contributed with more than one article, they all have a single initiative in the 10 years of our literature review. The journal contributes the most to this research is the Journal of Computer Assisted Learning with two articles [48,65]. It is important to define, and take into account, the country with the greatest presence in this analysis is the United States, with four initiatives, two in 2013 [48,57], and two in 2014 [56,67]. It is followed by the United Kingdom with three publications, one in 2010 [59], one in 2011 [31], and one in 2016 [65]. These results demonstrate the surprising interest in the benefits and problems that the adoption of mobile devices entails in current education (USA and UK). On the other hand, there are contributions from China [49,55], Australia [47,64], and Greece [45,52].

Table 6. Relevant studies on benefits and issues of education with mobile devices (2010-2020).

\begin{tabular}{|c|c|c|c|c|}
\hline Article & First Author & Journal/Proceedings/Conference & Year & Country \\
\hline [53] & Nemésio Freitas Duarte & Revista Iberoamericana de Tecnologías del Aprendizaje & 2015 & Brazil \\
\hline [44] & Muasaad Alrasheedi & $\begin{array}{l}\text { Proceedings of IEEE International Conference on Teaching, } \\
\text { Assessment and Learning for Engineering, TALE }\end{array}$ & 2013 & $\begin{array}{l}\text { Saudi } \\
\text { Arabia }\end{array}$ \\
\hline [49] & Simon Cheung & $\begin{array}{l}\text { Proceedings of IEEE International Symposium on IT in Medicine } \\
\text { and Education }\end{array}$ & 2011 & China \\
\hline$[50]$ & Kathrin Nitsche & $\begin{array}{l}\text { Proceedings of IEEE International Conference on Advanced } \\
\text { Learning Technologies }\end{array}$ & 2013 & Germany \\
\hline$[34]$ & Masoud Hashemi & Procedia-Social and Behavioral Sciences & 2011 & Iran \\
\hline [54] & Kubilay Özdoğan & $\begin{array}{l}\text { Proceedings of Portland International Center for Management of } \\
\text { Engineering and Technology: Technology Management for } \\
\text { Emerging Technologies }\end{array}$ & 2012 & Turkey \\
\hline [47] & R. Gurung & $\begin{array}{l}\text { Proceedings of the International Conference on Information and } \\
\text { Digital Technologies }\end{array}$ & 2016 & Australia \\
\hline [55] & Mingyong Zhang & $\begin{array}{l}\text { Proceedings of International Conference on Futuristic Trends in } \\
\text { Computational Analysis and Knowledge Management }\end{array}$ & 2015 & China \\
\hline$[52]$ & Angeliki Politi & Proceedings of IEEE Global Engineering Education Conference & 2017 & Greece \\
\hline [56] & Todd Cherner & Contemporary Issues in Technology and Teacher Education & 2014 & USA \\
\hline [57] & Brian Gilbert & Proceedings of IEEE Southeastcon & 2013 & USA \\
\hline [58] & Abeer Amer & $\begin{array}{l}\text { Proceedings of International Computer Engineering Conference: } \\
\text { Today Information Society What's Next? }\end{array}$ & 2011 & Egypt \\
\hline [59] & Don Passey & IEEE Transactions on Learning Technologies & 2010 & UK \\
\hline$[60]$ & Carina Rodrigues & $\begin{array}{l}\text { Proceedings of International Symposium on Computers in } \\
\text { Education }\end{array}$ & 2017 & Portugal \\
\hline [61] & Haji Ali Haji & Proceedings of IEEE Africon Conference & 2013 & Tanzania \\
\hline [62] & Santi Caballés & $\begin{array}{l}\text { Proceedings of Proceedings International Conference on P2P, } \\
\text { Parallel, Grid, Cloud and Internet Computing }\end{array}$ & 2015 & Spain \\
\hline [45] & Halima Hebiri Madani & $\begin{array}{l}\text { Proceedings of International Conference on Information and } \\
\text { Communication Technology and Accessibility }\end{array}$ & 2013 & Greece \\
\hline [63] & D. Seprilia & $\begin{array}{l}\text { Proceedings of International Conference on Informatics and } \\
\text { Computing }\end{array}$ & 2018 & Indonesia \\
\hline [64] & Sihong Zhang & International Journal of Emerging Technologies in Learning & 2016 & Australia \\
\hline$[65]$ & Neil Peter Morris & Journal of Computer Assisted Learning & 2016 & UK \\
\hline
\end{tabular}


Table 6. Cont.

\begin{tabular}{|c|c|c|c|c|}
\hline Article & First Author & Journal/Proceedings/Conference & Year & Country \\
\hline$[66]$ & Zouhair Rimale & International Journal of Interactive Mobile Technologies & 2016 & Morroco \\
\hline [67] & Evrim Baran & A Review of Research on Mobile Learning in Teacher Education & 2014 & USA \\
\hline [48] & katia ciampa & Journal of Computer Assisted Learning & 2013 & USA \\
\hline [31] & $\begin{array}{l}\text { Agnes } \\
\text { Kukulska-Hulme }\end{array}$ & International Journal of Mobile and Blended Learning & 2011 & UK \\
\hline [68] & Judith Bustillo & Sistemas y Telemática & 2017 & Colombia \\
\hline [69] & Dimiter G. Velev & International Journal of Information and Education Technology & 2014 & Bulgaria \\
\hline
\end{tabular}

Based on the research carried out, it can be indicated that there are empirical studies showing the benefits [55], problems [61], motivation [63], and impact [65] of the use of mlearning in education through the use of existing applications [68]. There are also initiatives that define a methodology for the design and construction of mobile applications for use in education $[52,57,63]$. These applications have several approaches. The first one is the teacher. For example, Gilbert, Wright, and Sukittanon [57] define it an application to deliver educational information to students in real-time. Politi and Metafas [52] report on the construction of a mobile application for the design, evaluation, and management of school projects. Another approach is the student, in this sense Madani et al. [45] focuses on the design of personalized and accessible m-learning systems for any student with a specific need or students with disabilities. The other approach is learning, Caballé, and Xhafa [62] define a prototype of a notification system for mobile devices that supports collaborative learning and online learning. Zhang [64] defines the benefits of using mobile applications as a pedagogical tool.

Also, it can be indicated that one of the main methods of addressing the problems of the use of mobile devices is mobile cloud computing (MCC) [66]. There is solid evidence the use of cloud services allows optimizing the performance of mobile devices, and this generates use intent and motivation in students [69]. Furthermore, certain problems can be avoided with the correct design of a methodology that involves mobile devices $[59,64]$. This can be achieved with the implementation of service-oriented architectures for mobile environments. It is also important to take teachers into account and involve them in initiatives that generate learning experiences [67]. This will achieve an agreement between teachers and the adoption of new technologies for the improvement of educational systems $[44,65]$.

\section{Limitations}

A literature review is always a snapshot of the broad field of knowledge at a particular moment [29]. Although the literature search followed a rigorous process to avoid any kind of bias, several articles may have been missed. On the other hand, the exclusion of works limits the number of possible extra initiatives and can lead to a variation in the result obtained. In this study, only articles written in English were considered, and we limited the search to initiatives have been published in conferences and journals on topics related to informatics and education. Another limitation of the research was the absence of the backward and forward snowballing technique. This step serves to include new works to the corpus of articles found with a review of the references of these. It was not applied because the number of initiatives found with the three-step methodology was adequate for the research objectives.

\section{Conclusions and Future Work}

The use of mobile technologies places the student at the center of the teaching-learning process, due to this the teacher is only the mediator between content and knowledge. Obviously, m-learning technology allows the inclusion of multiple learning models, thus managing to involve students in the construction of their own learning. 
Despite the issues inherent in mobile technology, initiatives to make m-learning part of the educational model are increasing day by day.

The results indicate that, in the future, m-learning will no longer be an option: The use of mobile devices will become a necessity in a modern educational system [82]. Today's generations of students have radically changed [11]. They are no longer the people for whom educational systems were designed. Today's students are used to multitasking processes [10]. Although the benefits of using this technology are outlined and robust, the issues must be addressed directly to avoid problems in the deployment and use of mobile technologies. The deployment of m-learning must be carried out with the collaboration of all the actors involved (educational institutions, teachers, and students) who are committed to the development of a new way of generating knowledge to motivate learning. The use of these mobile technologies must be possible for users without the need to read any type of manual. That is, it should be easy. Furthermore, the experience gained in the use of these devices should be enriching and very interesting. The mobility function can guide and support key educational stakeholders (students and teachers) in new and challenging learning situations, when and where needed.

Future work should focus on creating content-generating initiatives that are truly educational and truly support education. For these reasons, efforts should be made to integrate $\mathrm{m}$-learning into formal education properly.

In addition, in future research, due to the social impact, the demographic data of the students should be taken into account, such as their age, the ease of accessibility, and affordability of mobile technologies.

A scope for this research, or in the design of a new future initiative in which a literature review is used, it is advisable to include the technique of backward and forward snowballing. Applying this methodology can include new works that were not considered in the initial search, and can contribute new findings to the investigation.

Author Contributions: Conceptualization, S.C.-C. and S.L.-M.; methodology, S.C.-C., A.G.-A. and S.L.-M.; validation, S.C.-C. and S.L.-M.; formal analysis, S.C.-C. and S.L.-M.; investigation, S.C.-C., A.G.-A. and S.L.-M.; resources, S.C.-C., Á.J.-A. and S.L.-M.; data curation, S.C.-C., A.G.-A., Á.J.-A. and S.L.-M.; writing-original draft preparation, A.G.-A., S.C.-C. and S.L.-M.; writing-review and editing, S.C.-C., A.G.-A., Á.J.-A. and S.L.-M.; visualization, S.C.-C. and S.L.-M.; supervision, S.C.-C. and S.L.-M.; project administration, S.C.-C. and S.L.-M.; funding acquisition, S.L.-M. All authors have read and agreed to the published version of the manuscript.

Funding: This work was supported by the EduTech project (609785-EPP-1-2019-1-ES-EPPKA2CBHEJP) co-funded by the Erasmus+ Programme of the European Union.

Institutional Review Board Statement: Not Applicable.

Informed Consent Statement: Not Applicable.

Data Availability Statement: Not Applicable.

Conflicts of Interest: The authors declare no conflict of interest.

\section{References}

1. Fombona, J.; Pascual, M.A.; Ferra, M.P. Analysis of the Educational Impact of M-Learning and Related Scientific Research. J. New Approaches Educ. Res. 2020, 9, 167-180. [CrossRef]

2. Chu, H.C. Potential negative effects of mobile learning on students' learning achievement and cognitive load-A format assessment perspective. Educ. Technol. Soc. 2013, 17, 332-344.

3. Sobral, S.R. Mobile Learning in Higher Education: A Bibliometric Review. Int. J. Interact. Mob. Technol. 2020, 14, 153-170. [CrossRef]

4. Alhumaid, K. Four Ways Technology Has Negatively Changed Education. J. Educ. Soc. Res. 2019, 9, 10-20. [CrossRef]

5. McQuiggan, S.; Kosturko, L.; McQuiggan, J.; Sabourin, J. Mobile Learning: A Handbook for Developers, Educators, and Learners; Wiley: Hoboken, NJ, USA, 2015.

6. Krull, G.; Duart, J.M. Research Trends in Mobile Learning in Higher Education: A Systematic Review of Articles (2011-2015). Int. Rev. Res. Open Distrib. Learn. 2017, 18,1-23. [CrossRef]

7. Bleustein-Blanchet, M. Lead the Change. Train. Ind. Mag. 2016, 16-41. 
8. Cisco. Annual Internet Report (2018-2023). 2020. Available online: https://www.cisco.com/c/en/us/solutions/collateral/ executive-perspectives/annual-internet-report/white-paper-c11-741490.html (accessed on 19 April 2021).

9. Criollo-C, S.; Lujan-Mora, S.; Jaramillo-Alcazar, A. Advantages and Disadvantages of M-Learning in Current Education. In Proceedings of the 2018 IEEE World Engineering Education Conference (EDUNINE), Buenos Aires, Argentina, 30 August 2018; pp. 1-6. [CrossRef]

10. Dingli, A.; Seychell, D. The New Digital Natives; J.B. Metzler: Stuttgart, Germany, 2015.

11. Prensky, M. Digital Natives, Digital Immigrants. Digit. Nativ. Digit. Immigr. 2001, 9, 1-6.

12. Al-Hunaiyyan, A.; Alhajri, R.A.; Al-Sharhan, S. Perceptions and challenges of mobile learning in Kuwait. J. King Saud Univ. Comput. Inf. Sci. 2018, 30, 279-289. [CrossRef]

13. UNESCO. World Conference on Higher Education, The United Nations Educational, Scientific and Cultural Organization. 1990. Available online: http:/ / www.unesco.org/new/en/education/themes/leading-the-international-agenda/education-for-all/theefa-movement/jomtien-1990/ (accessed on 10 August 2020).

14. Parras-Burgos, D.; Fernández-Pacheco, D.G.; Barbosa, T.P.; Soler-Méndez, M.; Molina-Martínez, J.M. An Augmented Reality Tool for Teaching Application in the Agronomy Domain. Appl. Sci. 2020, 10, 3632. [CrossRef]

15. Kukulska-Hulme, A.; Viberg, O. Mobile collaborative language learning: State of the art. Br. J. Educ. Technol. 2018, 49, 207-218. [CrossRef]

16. Criollo-C, S.; Luján-Mora, S. M-Learning and Their Potential use in the Higher Education: A Literature Review. In Proceedings of the 2017 International Conference on Information Systems and Computer Science (INCISCOS), Quito, Ecuador, 23-25 November 2017; pp. 268-273. [CrossRef]

17. Neufeld, P.G.; DelCore, H.D. Situatedness and Variations in Student Adoption of Technology Practices: Towards a Critical Techno-Pedagogy. J. Inf. Technol. Educ. Res. 2018, 17, 001-038. [CrossRef]

18. McClean, S.; Crowe, W. Making room for interactivity: Using the cloud-based audience response system Nearpod to enhance engagement in lectures. FEMS Microbiol. Lett. 2017, 364, 1-7. [CrossRef]

19. Zydney, J.M.; Warner, Z. Mobile apps for science learning: Review of research. Comput. Educ. 2016, 94, 1-17. [CrossRef]

20. Kearney, M.; Burden, K.; Schuck, S. Disrupting Education Using Smart Mobile Pedagogies. Didact. Smart Pedagog. 2018, 139-157. [CrossRef]

21. Fombona Cadavieco, A.; Pascual Sevillano, M.; González Videgaray, M. M-learning y realidad aumentada: Revisión de literatura científica en el repositorio WoS. Comunicar Revista Científica Iberoamericana Comunicación Educación 2017, 52, 63-72. [CrossRef]

22. Traxler, J. Inclusion in an age of mobility. Res. Learn. Technol. 2016, 24. [CrossRef]

23. Briz-Ponce, L.; Pereira, A.; Carvalho, L.; Juanes-Méndez, J.A.; García-Peñalvo, F.J. Learning with mobile technologies-Students' behavior. Comput. Hum. Behav. 2017, 72, 612-620. [CrossRef]

24. Shuja, A.; Qureshi, I.A.; Schaeffer, D.M.; Zareen, M. Effect of m-learning on students' academic performance mediated by facilitation discourse and flexibility. Knowl. Manag. E Learn. Int. J. 2019, 11, 158-200. [CrossRef]

25. Belle, L.J. An Evaluation of a Key Innovation: Mobile Learning. Acad. J. Interdiscip. Stud. 2019, 8, 39-45. [CrossRef]

26. Kitchenham, B. Procedures for Performing Systematic Reviews; Keele University: Keele, UK, 2004.

27. Kitchenham, B.A.; Budgen, D.; Brereton, O.P. The Value of Mapping Studies-A Participant-Observer Case Study. In Proceedings of the 14th International Conference on Evaluation and Assessment in Software Engineering (EASE), Keele, UK, 12-13 April 2010. [CrossRef]

28. Wainaina, P.K.; Maina, E.M.; Nzuki, D.M. A Review of Mobile Learning Considerations in Open Distance Learning and Access to Higher Education. In Proceedings of the 2019 IST-Africa Week Conference (IST-Africa), Nairobi, Kenya, 8-10 May 2019. [CrossRef]

29. Crompton, H.; Burke, D. The use of mobile learning in higher education: A systematic review. Comput. Educ. 2018, 123, 53-64. [CrossRef]

30. Alrasheedi, M.; Capretz, L.F.; Raza, A. A Systematic Review of the Critical Factors for Success of Mobile Learning in Higher Education (University Students' Perspective). J. Educ. Comput. Res. 2015, 52, 257-276. [CrossRef]

31. Kukulska-Hulme, A.; Pettit, J.; Bradley, L.; Carvalho, A.A.; Herrington, A.; Kennedy, D.M.; Walker, A. Mature Students Using Mobile Devices in Life and Learning. Int. J. Mob. Blended Learn. 2011, 3, 18-52. [CrossRef]

32. Sattler, B.; Spyridakis, I.; Dalal, N.; Ramey, J. The Learning Experience: A Literature Review of the Role of Mobile Technology. In Proceedings of the IEEE International Professional Comunication Conference 2010, Enschede, The Netherlands, 7-9 July 2010; pp. 38-45. [CrossRef]

33. Criollo-C, S.; Luján-Mora, S. A SWOT analysis of bring your own devices in mobile learning. In Proceedings of the International Conference on Mobile Learning, Portugal, 14-16 April 2018; pp. 148-152.

34. Hashemi, M.; Azizinezhad, M.; Najafi, V.; Nesari, A.J. Retracted: What is Mobile Learning? Challenges and Capabilities. Procedia Soc. Behav. Sci. 2011, 30, 2477-2481. [CrossRef]

35. Criollo-C, S.; Luján-Mora, S. Encouraging Student Motivation through Gamification in Engineering Education. Adv. Hum. Factors Bus. Manag. Train. Educ. 2019, 909, 204-211. [CrossRef]

36. Bucea-Manea-Toniş, R.; Bucea-Manea-Toniş, R.; Simion, V.E.; Ilic, D.; Braicu, C.; Manea, N. Sustainability in Higher Education: The Relationship between Work-Life Balance and XR E-Learning Facilities. Sustainability 2020, 12, 5872. [CrossRef] 
37. Vakaliuk, T.A.; Shevchuk, L.D.; Shevchuk, B.V. Possibilities of Using AR and VR Technologies in Teaching Mathematics to High School Students. Univers. J. Educ. Res. 2020, 8, 6280-6288. [CrossRef]

38. Cakmak, Y.O.; Daniel, B.K.; Hammer, N.; Yilmaz, O.; Irmak, E.C.; Khwaounjoo, P. The Human Muscular Arm Avatar as an Interactive Visualization Tool in Learning Anatomy: Medical Students' Perspectives. IEEE Trans. Learn. Technol. 2020, 13, 593-603. [CrossRef]

39. Mierlus-Mazilu, I. M-learning Objects. In Proceedings of the 2010 International Conference on Electronics and Information Engineering, Kyoto, Japan, 1-3 August 2010; pp. 113-117. [CrossRef]

40. Keengwe, J.; Schnellert, G.; Jonas, D. Mobile phones in education: Challenges and opportunities for learning. Educ. Inf. Technol. 2012, 19, 441-450. [CrossRef]

41. Dimock, M. Donde terminan los Millennials y Comienza la Generación Z. Pew Research Center. 2019. Available online: https: //www.pewresearch.org/fact-tank/2019/01/17/where-millennials-end-and-generation-z-begins/ (accessed on 10 August 2020).

42. Khaddage, F.; Müller, W.; Flintoff, K. Advancing mobile learning in formal and informal settings via mobile app technology: Where to from here, and how? Educ. Technol. Soc. 2016, 19, 16-26.

43. Cheng, Y.-M. Towards an understanding of the factors affecting m-learning acceptance: Roles of technological characteristics and compatibility. Asia Pac. Manag. Rev. 2015, 20, 109-119. [CrossRef]

44. Alrasheedi, M.; Capretz, L.F. A Meta-Analysis of Critical Success Factors Affecting Mobile Learning. In Proceedings of the 2013 IEEE International Conference on Teaching, Assessment and Learning for Engineering (TALE), Bali, Indonesia, 26-29 August 2013; pp. 262-267. [CrossRef]

45. Madani, H.H.; Ben Ayed, L.J.; Jemni, M.; Sampson, D.G. Towards Accessible and Personalized Mobile Learning for Learners with Disabilities. In Proceedings of the Fourth International Conference on Information and Communication Technology and Accessibility (ICTA), Hammamet, Tunisia, 24-26 October 2013; pp. 1-6. [CrossRef]

46. Crompton, H.; Burke, D.; Gregory, K.H.; Gräbe, C. The Use of Mobile Learning in Science: A Systematic Review. J. Sci. Educ. Technol. 2016, 25, 149-160. [CrossRef]

47. Gurung, R.K.; Alsadoon, A.; Prasad, P.; Elchouemi, A. Impacts of Mobile Cloud Learning (MCL) on Blended Flexible Learning (BFL). In Proceedings of the 2016 International Conference on Information and Digital Technologies (IDT), Rzeszow, Poland, 5-7 July 2016; pp. 108-114. [CrossRef]

48. Ciampa, K. Learning in a mobile age: An investigation of student motivation. J. Comput. Assist. Learn. 2013, 30, 82-96. [CrossRef]

49. Cheung, S.K.; Yuen, K.; Tsang, E.Y. A Study on the Readiness of Mobile Learning in Open Education. In Proceedings of the 2011 IEEE International Symposium on IT in Medicine and Education, Guangzhou, China, 9-11 December 2011; pp. 133-136. [CrossRef]

50. Nitsche, K. Acceptance of Mobile, Classroom-Bound E-Learning Systems from the Perspective of Students and Lectures. In Proceedings of the 13th International Conference on Advanced Learning Technologies, Beijing, China, 15-18 July 2013; pp. 508-509. [CrossRef]

51. Hamidi, H.; Chavoshi, A. Analysis of the essential factors for the adoption of mobile learning in higher education: A case study of students of the University of Technology. Telemat. Inform. 2018, 35, 1053-1070. [CrossRef]

52. Metafas, D.; Politi, A. Mobile-Assisted Learning: Designing Class Project Assistant, a Research-Based Educational App for Project Based Learning. In Proceedings of the 2017 IEEE Global Engineering Education Conference (EDUCON), Athens, Greece, 25-28 April 2017; pp. 667-675. [CrossRef]

53. Filho, N.F.D.; Barbosa, E.F. A Contribution to the Establishment of Reference Architectures for Mobile Learning Environments. IEEE Rev. Iberoam. Tecnol. Aprendiz. 2015, 10, 234-241. [CrossRef]

54. Özdoğan, K.M.; Başoğlu, N.; Erçetin, G. Exploring Major Determinants of Mobile Learning Adoption. Proceedings of Portland International Center for Management of Engineering and Technology: Technology Management for Emerging Technologies, PICMET, Vancouver, BC, Canada, 29 July-2 August 2012; pp. 1415-1423.

55. Mingyong, Z. Investigation into the Use of Mobile Technology in English Teaching and Learning in Institutes of Higher Vocational Education in Hubei Province in China. In Proceedings of the 2015 International Conference on Futuristic Trends on Computational Analysis and Knowledge Management (ABLAZE), Greater Noida, India, 25-27 February 2015; pp. 505-509. [CrossRef]

56. Cherner, T.; Dix, J.; Lee, C. Cleaning Up That Mess: A Framework for Classifying Educational Apps. Contemp. Issues Technol. Teach. Educ. 2014, 14, 158-193. [CrossRef]

57. Gilbert, B.; Wright, B.; Sukittanon, S. Mobile Authoring and Sharing System for Creating Learning Materials. In Proceedings of the 2013 IEEE Southeastcon, Jacksonville, FL, USA, 4-7 April 2013; pp. 1-4. [CrossRef]

58. Amer, A.A.; Hafez, H.A.A. Mobile Learning Concepts and its Effects on Student's Attitudes in Egypt. In Proceedings of the 2011 Seventh International Computer Engineering Conference (ICENCO' 2011), Cairo, Egypt, 27-28 December 2011 ; pp. $43-48$.

59. Passey, D. Mobile Learning in School Contexts: Can Teachers Alone Make It Happen? IEEE Trans. Learn. Technol. $2009,3,68-81$. [CrossRef]

60. Rodrigues, C.; Morgado, L. Seniors Online: Survey Analysis of the Appropriation of Touch-Based Mobile Devices in Learning Settings. In Proceedings of the 2017 International Symposium on Computers in Education (SIIE), Lisbon, Portugal, 9-11 November 2017; pp. 1-6. [CrossRef] 
61. Haji, H.A.; Abu Shaame, A.; Kombo, O. The Opportunities and Challenges in Using Mobile Phones as Learning Tools for Higher Learning Students in the Developing Countries: Zanzibar context. In Proceedings of the 2013 Africon, Pointe aux Piments, Mauritius, 9-12 September 2013; pp. 1-5. [CrossRef]

62. Caballe, S.; Xhafa, F. Towards a Notification System for Mobile Devices to Support Collaborative Learning. In Proceedings of the 10th International Conference on P2P, Parallel, Grid, Cloud and Internet Computing (3PGCIC), Krakow, Poland, 4-6 November 2015; pp. 70-76. [CrossRef]

63. Seprilia, D.; Handayani, P.; Pinem, A. User Acceptance Factors Affecting the Usage of Mobile Learning in Enriching Outside Classroom Learning at High School Level. In Proceedings of the 2017 Second International Conference on Informatics and Computing (ICIC), Jayapura, Indonesia, 1-3 November 2017; pp. 1-6. [CrossRef]

64. Zhang, S. Mobile English Learning: An Empirical Study on an APP, English Fun Dubbing. Int. J. Emerg. Technol. Learn. 2016, 11, 4-8. [CrossRef]

65. Morris, N.; Lambe, J.; Ciccone, J.; Swinnerton, B. Mobile technology: Students perceived benefits of apps for learning neuroanatomy. J. Comput. Assist. Learn. 2016, 32, 430-442. [CrossRef]

66. Rimale, Z.; El Habib, B.L.; Tragha, A.; El Guemmat, K. Survey on the Use of the Mobile Learning Based on Mobile Cloud Computing. Int. J. Interact. Mob. Technol. 2016, 10, 35-41. [CrossRef]

67. Baran, E. A review of research on mobile learning in teacher education. Educ. Technol. Soc. 2014, 17, 17-32.

68. Bustillo, J.; Rivera, C.; Guzmán, J.G.; Acosta, L.R. Benefits of using a mobile application in learning a foreign language. Sist. Telemática 2017, 15, 55-68. [CrossRef]

69. Velev, D.G. Challenges and Opportunities of Cloud-Based Mobile Learning. Int. J. Inf. Educ. Technol. 2014, 4, 49-53. [CrossRef]

70. Zheng, W.; Pan, H.; Peng, Y.-S. Explore the Ubiquitous Learning on Campus: A Friendship-Based Knowledge Diffusion Approach. IEEE Access 2018, 6, 56238-56245. [CrossRef]

71. Gros, B. The design of smart educational environments. Smart Learn. Environ. 2016, 3, 15. [CrossRef]

72. Pimmer, C.; Mateescu, M.; Gröhbiel, U. Mobile and ubiquitous learning in higher education settings. A systematic review of empirical studies. Comput. Hum. Behav. 2016, 63, 490-501. [CrossRef]

73. Gumeta, H.; Khan, J. Where is Mobile Learning Going in China? In Proceedings of the 11th International Technology, Education and Development Conference, Valencia, Spain, 6-8 March 2017; pp. 2750-2759. [CrossRef]

74. Denk, M.; Weber, M.; Belfin, R. Mobile learning—challenges and potentials. Int. J. Mob. Learn. Organ. 2007, 1, 122-139. [CrossRef]

75. Karimi, S. Do learners' characteristics matter? An exploration of mobile-learning adoption in self-directed learning. Comput. Hum. Behav. 2016, 63, 769-776. [CrossRef]

76. Burden, K.; Hopkins, P. Barriers and Challenges Facing Pre-Service Teachers use of Mobile Technologies for Teaching and Learning. Int. J. Mob. Blended Learn. 2016, 8, 1-20. [CrossRef]

77. Platzer, E.; Petrovic, O. A Learning Environment for Developers of Mobile Apps. In Proceedings of the 2011 IEEE Global Engineering Education Conference (EDUCON), Amman, Jordan, 4-6 April 2011; pp. 14-19. [CrossRef]

78. Haag, J. From eLearning to mLearning: The Effectiveness of Mobile Course Delivery. Ind. Train. Simul. Educ. Conf. 2011, 2011, $1-13$.

79. Fatimah, W.; Ahmad, W. Cloud Computing Role to Address Mobile Learning Barriers: An Exploratory Study of HEIs in Malaysia. In Proceedings of the 2016 3rd International Conference on Computer and Information Sciences (ICCOINS), Kuala Lumpur, Malaysia, 15-17 August 2016; pp. 553-558. [CrossRef]

80. Ting, R.Y.-L. Mobile Learning: Current Trend and Future Challenges. In Proceedings of the Fifth IEEE International Conference on Advanced Learning Technologies (ICALT'05), Kaohsiung, Taiwan, 5-8 July 2005; pp. 603-607. [CrossRef]

81. Bano, M.; Zowghi, D.; Kearney, M.; Schuck, S.; Aubusson, P. Mobile learning for science and mathematics school education: A systematic review of empirical evidence. Comput. Educ. 2018, 121, 30-58. [CrossRef]

82. Al Dhaheri, L.; Ezziane, Z. Mobile learning technologies for 21st-century educators: opportunities and challenges in the UAE. Int. J. Mob. Learn. Organ. 2015, 9, 218. [CrossRef] 